\title{
PENGGUNAAN AC/ID DAN ACTIVE LEARNING DALAM PEMBELAJARAN ANATOMI DALAM LARGE GROUP
}

\author{
Siti Munawaroh
}

Bagian Anatomi dan Embriology, Universitas Sebelas Maret Surakarta

\begin{abstract}
Background: Anatomy is a basic medical science that very important for medical students and other health professions. With a good understanding of the anatomy, they can understand the condition of the patient's illness. However, many of students who complain about the difficulty of anatomy. This paper aims to provide an alternative choice of instructional design in large classes (large group) to improve the quality of learning.

Method: literature review.

Results: There are many designs of learning that can be applied in a large group. Each has advantages and disadvantages. To improve the quality of student learning, need to be actively involved students in the learning process, so that the material being studied can understand and survive long in the memory of the student.

Conclusion: Management of the large group on anatomy lesson is required to produce effective learning. One of the instructional design that can be applied to achieve these objectives is the $4 \mathrm{C} / \mathrm{ID}$ by applying the principles of active learning.
\end{abstract}

Keywords: anatomy lessons, large group, 4C / ID, active learning

\section{ABSTRAK}

Latar belakang: Anatomi adalah materi dasar yang sangat penting bagi mahasiswa kedokteran dan profesi kesehatan lainnya. Dengan pemahaman yang baik terhadap materi anatomi, mereka dapat memahami kondisi penyakit pasien. Namun demikian, banyak diantara mereka yang mengeluhkan sulitnya materi anatomi. Tulisan ini bertujuan untuk memberikan alternatif pilihan desain pembelajaran di kelas besar (large group) yang sesuai untuk dapat meningkatkan kualitas pembelajaran.

Metode: literatur review.

Hasil: Terdapat banyak desain pembelajaran yang dapat diterapkan di kelas besar. Masing-masing memiliki kelebihan dan kekurangan. Untuk meningkatkan kualitas pembelajaran maka perlu keterlibatan mahasiswa secara aktif dalam proses pembelajaran, sehingga materi yang dipelajari dapat masuk dan bertahan lama dalam memori mahasiswa.

Kesimpulan: Manajemen pembelajaran anatomi pada large group diperlukan untuk menghasilkan pembelajaran yang efektif. Salah satu desain pembelajaran yang bisa diterapkan untuk mencapai tujuan tersebut adalah 4C/ID dengan menerapkan prinsip pembelajaran active learning.

Kata kunci: pembelajaran anatomi, large group, 4C/ID, active learning

Korespondensi: munafkuns@gmail.com 


\section{PENDAHULUAN}

Anatomi merupakan ilmu dasar dalam kedokteran. Anatomi menjadikan seorang dokter mampu memahami kondisi penyakit pasien dengan baik. Selain dokter, anatomi juga diperlukan sebagai dasar oleh perawat, bidan, dokter gigi, fisioterapi dan semua profesi yang berkaitan kesehatan. ${ }^{1}$

Meskipun anatomi merupakan ilmu dasar, banyak mahasiswa yang mengeluhkan tentang sulitnya materi ini. Hal ini sudah berlaku sejak zaman dahulu, seperti yang dialami oleh penulis dan teman-temannya pada saat masih kuliah S1 kedokteran. Saat ini "momok" tersebut masih ada, terbukti dari pernyataan beberapa mahasiswa yang penulis ampu di materi anatomi yang menyatakan bahwa anatomi itu sulit.

Selama ini, pembelajaran anatomi dilakukan dalam bentuk perkuliahan di kelas besar dan praktikum. Sebagian kecil juga dipelajari dalam diskusi tutorial. Kali ini penulis akan fokus pada kuliah anatomi di kelas besar pada mahasiswa paramedis seperti perawat, bidan, hiperkes, kesehatan kerja dan farmasi. Karena pada kelas paramedis ini kuliah anatomi dilakukan secara berkesinambungan mulai dari pengantar anatomi hingga anatomi tiap organ di dalam sistem tubuh manusia. Sedangkan pada mahasiswa kedokteran materi anatomi diberikan sesuai dengan tema blok yang sedang berjalan.

Penulis berusaha mencari solusi berdasarkan apa yang penulis pelajari dalam medical education terutama tentang "facilitating leaming" dengan menyesuaikan kondisi mahasiswa di lapangan agar tercapai pembelajaran anatomi yang efektif sehingga harapannya mahasiswa tidak lagi berkomentar bahwa anatomi itu sulit.

\section{METODE}

Literatur yang relevan dipilih sebagai dasar untuk melakukan review.

\section{HASIL DAN PEMBAHASAN}

Terjadi banyak perubahan dalam pendidikan kedokteran beberapa tahun terakhir salah satu bentuk perubahan tersebut adalah tuntutan akan self-directed learning dimana mahasiswa diharapkan dapat lebih bertanggung jawab terhadap proses belajarnya. Selain itu juga terjadi pergeseran pada peran dosen, dimana sebelumnya sistem teacher centered learning menuntut dosen berperan sebagai dispenser yang selalu menyediakan informasi untuk mahasiswa berubah menjadistudent centered learning yang lebih banyak memberikan tanggung jawab dan kebebasan kepada mahasiswa terhadap proses belajarnya sehingga disini dosen berperan sebagai fasilitator atau manajer terhadap proses belajar mahasiswa. ${ }^{2}$

Sebagian besar center pendidikan kesehatan di Indonesia menerapkan kurikulum berbasis kompetensi yang menggunakan model pendekatan belajar berdasar masalah (Problem Based Learning/ PBL) sebagai intinya. Model pendekatan ini memberikan keuntungan bagi mahasiswa dalam penerapan anatomi dalam praktik klinis. Hal itu disebabkan karena peran anatomi sangat luas dalam praktik kedokteran, yakni meliputi pemeriksaan fisik, tindakan akses arteri dan vena, pembedahan, dan penanganan berbagai manifestasi trauma yang memerlukan logika berdasarkan pengetahuan anatomi. ${ }^{3}$

Namun demikian kurikulum ini tidak menjadikan kuliah di kelas besar menjadi hilang, karena terdapat laporan hasil studi yang menyatakan bahwa kurikulum anatomi yang terintegrasi mempunyai dampak negatif terhadap pengetahuan mahasiswa mengenai surface anatomi, ${ }^{4}$ sehingga pengajaran materi anatomi secara tersendiri melalui model perkuliahan tetap dipandang perlu, dan dapat digunakan secara bersama-sama pada kurikulum PBL.

\section{Kekurangan dan kelebihan kuliah}

Beberapa teoritikus mengkritik bahwa kuliah menempatkan mahasiswa dalam peran pasif, dimana mereka duduk manis mendengarkan ceramah yang disampaikan oleh dosen pemberi kuliah. Dari sudut pandang behavioris, para siswa belajar hanya ketika mereka memberikan respon secara aktif. Meskipun demikian banyak ahli kognitif mengemukakan bahwa seringkali mahasiswa aktif secara mental selama aktivitasaktivitas yang tampaknya pasif tersebut. Dari sudut pandang psikologi kognitif, sejauh mana mahasiswa belajar dari kuliah tergantung bagaimana mereka memproses informasi, artinya, tergantung pada responrespon kognitif tertentu yang mereka buat. Semakin besar 
perhatian siswa, semakin besar keterlibatan mereka dalam pembelajaran yang bermakna, pengorganisasian, elaborasi dan sebagainya, serta semakin besar pula mereka mendapat manfaat dari kegiatan kuliah yang mereka ikuti. ${ }^{5,6}$

Meskipun banyak mendapat komentar negatif, kuliah memiliki peranan penting dalam program pendidikan, misalnya ketika dosen hendak memperkenalkan suatu materi baru, merangsang rasa ingin tahu mahasiswa, menyampaikan topik yang sulit, menyampaikan perspektif yang berbeda terhadap suatu subjek dan resume penelitian terbaru, ${ }^{7,8}$ serta membantu mahasiswa mengaplikasikan pengetahuan mereka dan menggunakannya dalam menganalisis masalah ${ }^{5}$ dan berpikir kritis. ${ }^{6}$ Selain itu, kelebihan model pembelajaran dalam bentuk perkuliahan kelas besar adalah bahwa informasi dapat diberikan secara ekonomis, cepat dan efisien. ${ }^{5,8}$

Kerugian utama perkuliahan adalah tidak memungkinkan dosen menilai kemajuan belajar siswa. Selain itu, tidak semua dosen memiliki kemampuan yang baik dalam menyampaikan informasi, sehingga akan menjadi masalah ketika dosen menyampaikan materi secara tidak terorganisir, tidak terstruktur, tidak informatif dan hanya menyampaikan hafalan terhadap text tanpa merangsang pengembangan pemahaman. Hal ini dapat menjadikan mahasiswa bosan juga tidak termotivasi. ${ }^{5,8}$

Dalam sebuah analisis yang disampaikan oleh Brown and Manogue (2001) menyebutkan bahwa penyampaian metodologi dan teori akan lebih efektif disampaikan dalam kuliah. ${ }^{8}$ Sehingga materi anatomi yang termasuk materi dasar pun akan lebih tepat jika disampaikan dalam bentuk perkuliahan dengan tetap memberikan sesi praktikum sebagai pendalaman.

\section{Bagaimana merancang pembelajaran yang efektif} dalam kuliah?

Gagne, Briggs and Wager (1992) lebih menyukai menyebut dengan istilah "instruction" daripada "teaching" karena mereka berharap agar semua hal mempunyai efek langsung terhadap proses belajar mahasiswa, tidak sekedar kejadian yang berpusat terhadap apa yang dilakukan oleh dosen. Tentunya dosen mempunyai peranan yang sangat penting dalam merencanakan instruksi untuk mahasiswa. ${ }^{10}$

Penggunaan desain instruksional pada aktivitas pembelajaran dirasa sangat penting untuk mengarahkan mahasiswa bagaimana sebuah instruksi berupa masalah, dengan dukungan informasi dan penugasan, dapat mencapai tujuan belajar yang diharapkan. ${ }^{7}$ Tujuan dari desain instruksional adalah untuk mengaktifkan dan mendukung proses belajar mahasiswa. Sehingga harus direncanakan dengan baik, tidak secara sembarangan dilakukan. $^{8}$

Banyak sekali desain instruksional yang ada dalam dunia pendidikan, seperti Desain 4C/ID (4 component design instructional), JIT (Just in Time), ADDIE (Analyze, Design, Development, Implementation and Evaluation), ${ }^{9}$ sembilan unsur desain Gagne dan masih banyak yang lainnya. Disini penulis akan fokus pada 4C/ID.

4C/ID (4 component design instructional) adalah desain instruksional yang terdiri atas empat tahapan yaitu pemberian tugas, pemberian informasi penunjang, pemberian informasi prosedural dan praktik sebagian tugas (Part-Task Practice). Desain instruksional ini memiliki keunggulan untuk membentuk organisasi pembelajaran yang memiliki topik belajar yang rumit dan digunakan untuk mendesain sebuah pelatihan atau kursus. ${ }^{10}$

Selain menyiapkan desain instruksional untuk perkuliahan, sebaiknya dosen melihat buku panduan mahasiswa ataupun kurikulum untuk menilai pengetahuan atau pengalaman apa yang sudah dimiliki oleh mahasiswa. ${ }^{5,7}$ Kemudian rencanakan materi perkuliahan dengan mengidentifikasi konsep dan prinsip penting materi tersebut serta identifikasi konsep-konsep sulit yang akan membuat mahasiswa bekerja keras untuk bisa memahaminya. Cara mengetahui mana saja konsep yang sulit bisa dengan berdiskusi dengan dosen lain dan menanyakan kepada mahasiswa tahun sebelumnya yang mendapatkan materi yang sama atau dengan melihat hasil ujian mereka. Konsep yang sulit ini membutuhkan perhatian yang lebih, bisa dengan memberikan analogi dan contoh-contoh, serta memberikan kesempatan kepada mahasiswa untuk menjelaskan pemahaman mereka terhadap konsep tersebut. $^{11}$ 
Sesekali perlu kiranya untuk mereview materi yang akan diberikan. Kurangi hal-hal yang dirasa kurang penting. Karena dalam perkuliahan mahasiswa sering merasa overload dimana kemampuan otak untuk mencerna materi terbatas. Sehingga prinsip "sedikit itu lebih baik" sangatlah tepat untuk merencanakan perkuliahan. ${ }^{11}$

Perhatian mahasiswa terhadap perkuliahan sangatlah diperlukan untuk tercapainya kuliah yang efektif. Sehingga dosen harus mampu mendesain aktivitas perkuliahan agar menarik perhatian mahasiswa. Beberapa cara yang dapat dilakukan diantaranya menyampaikan problem nyata di awal perkuliahan, dan menanyakan kepada mahasiswa bagaimana solusi permasalahan tersebut. Tentunya masalah yang disampaikan berkaitan dengan materi yang akan dibahas. Sehingga mahasiswa menjadi tertarik untuk mengikuti perkuliahan. Selain itu bisa juga dengan menayangkan video atau presentasi kasus terkait dengan materi yang disampaikan. Cara lainnya bisa dengan memberikan pretes terkait materi di awal perkuliahan sehingga mahasiswa dapat menilai pengetahuaanya dan soal yang sama dapat pula diberikan di akhir perkuliahan untuk mengetahui keberhasilan mahasiswa dalam menyerap materi yang disampaikan. ${ }^{11}$

Selain menarik perhatian mahasiswa, perlu kiranya agar proses perkuliahan memungkinkan mahasiswa untuk terlibat aktif di dalamnya. Karena sesuai dengan teori belajar konstruktivisme pembelajaran bermakna akan bisa di dapatkan ketika mahasiswa secara aktif memproses informasi baru, menginterpretasikannya dan menhubungkan dengan pengetahuan yang telah dimilikinya, sehingga dapat meningkatkan retensi terhadap ilmu yang diperoleh dalam perkuliahan. ${ }^{12} \mathrm{Hal}$ ini sejalan dengan apa yang telah disampaikan oleh Chilwant (2012) dalam penelitiannya terhadap mahasiswa yang diberikan kuliah farmakologi secara interaktif terstruktur dibandingkan dengan mahasiswa yang diberi kuliah secara konvensional. Hasil penelitian menunjukkan tidak ada perbedaan yang signifikan antara kedua kelompok, akan tetapi kelompok perlakuan menunjukkan bahwa kuliah interaktif terstruktur meningkatkan ketertarikan mahasiswa terhadap materi, materi terasa lebih simple dan meningkatkan motivasi mahasiswa untuk belajar mandiri. ${ }^{6}$

\section{Active Learning}

Mahasiswa adalah pemeran yang aktif dalam lingkungan pembelajaran dan tidak semata-mata sebagai konsumen yang menerima secara pasif materi dari dosennya. ${ }^{13}$ Dengan berinteraksi secara aktif dengan mahasiswa, akan terjalin hubungan personal yang lebih erat dibandingkan bila dosen terfokus untuk memberi kuliah sehingga kurang memperhatikan mahasiswanya. ${ }^{14}$

Pembelajaran aktif (active learning) adalah sebuah proses yang melibatkan mahasiswa dalam melakukan suatu tindakan dan memberi kesempatan kepada mereka untuk memikirkan apa yang mereka lakukan tersebut. Ketika mahasiswa menjadi pembelajar aktif di dalam kelas maka mereka sedang terlibat dalam proses berpikir tingkat tinggi, yaitu analisis, sintesis dan evaluasi. Untuk menjaga proses ini maka ada beberapa hal yang harus diperhatikan. Diantaranya, pertama makna aktif tidak hanya sekedar aktif, tetapi mahasiswa harus memahami apa yang dia lakukan dan bagaimana kaitannya dengan tujuan perkuliahan. Kedua, evaluasi dan feedback yang diberikan harus sesuai dengan tujuan pembelajaran aktif, dosen sebaiknya menghubungkan pemahaman mahasiswa mengenai proses daripada materi spesifik, penilaian tinggi sebaiknya diberikan kepada mahasiswa yang mampu memformulasikan permasalahan dengan baik. $^{12}$

Terlepas dari betapa pentingnya pembelajaran aktif bagi mahasiswa, sebagian besar dari mahasiswa sering memposisikan diri sebagai pembelajar yang pasif, hanya menerima apa yang akan disampaikan oleh sang dosen. Alasan utama mengapa bisa timbul situasi ini adalah karena banyak diantara para dosen yang jarang melibatkan mahasiswa dalam proses pembelajaran di dalam kelas perkuliahan mereka. Berikut adalah beberapa hal yang menjadi alasan mengapa para dosen tidak menerapkan pembelajaran aktif beserta jawabannya yang disampaikan dalam buku Hativa $(2000)^{14}:$

1. Buang-buang waktu. Dosen merasa bahwa dengan melibatkan mahasiswa agar aktif dalam pembelajaran di kelas akan membuang waktu. Waktu perkuliahan yang sempit akan menjadikan materi tidak tersampaikan dengan sempurna 
Jawaban: jawaban dari alasan ini adalah bahwa dosen tidak perlu menyampaikan semua materi dalam perkuliahan di kelas mereka tersebut, tetapi doronglah mahasiswa untuk belajar mandiri dan sampaikanlah hal-hal yang sekiranya perlu mahasiswa ingat 5 tahun yang akan datang. Karena keaktifan mahasiswa akan menjadikan proses belajar menjadi lebih efektif sehingga bisa menjadikan mahasiswa mampu mengingat apa yang dipelajarinya dalam jangka waktu lama. $\mathrm{Hal}$ ini sejalan dengan apa yang disampaikan Harden (2001) mengatakan bahwa tidak semua isi materi disampaikan, melainkan hanya materi inti saja, sedangkan yang lainnya bisa disampaikan dalam kesempatan atau cara lain selain kuliah. ${ }^{17}$

2. Lepas kontrol. Beberapa dosen merasa dengan melibatkan mahasiswa dalam kegiatan pembelajaran aktif di kelas akan menjadikan kuliah menjadi lepas kontrol, serta timbul kekacauan dan mereka juga tidak menyukai akan ketidakpastian yang mungkin terjadi di kelas yang belum mereka persiapkan.

Jawaban: jika dosen telah merencanakan dan mengorganisasikan dengan baik maka mahasiswa akan ikut terlibat dan tertantang dalam pembelajaran di kelas dan dosen tetap mampu memegang kendali akan keberlangsungan proses pembelajaran.

3. Ketidaksiapan mahasiswa. Para dosen sering menjadikan hal ini sebagai alasan, karena beranggapan bahwa mahasiswa mereka belum siap terhadap materi yang akan disampaikan di kelas.

Jawaban: permasalahan ini bisa diatasi dengan memberi motivasi kepada mahasiswa untuk membaca materi yang akan dipelajari. Motivasi itu bisa berupa memberi pertanyaan yang mengarahkan kepada pembahasan materi di perkuliahan, bisa berupa pemberian pretes $\mathrm{di}$ awal perkuliahan.

Pembelajaran aktif terdiri dari beberapa elemen dasar (berbicara, mendengar, menulis, membaca dan refleksi), strategi belajar (kelompok kecil, tugas kelompok, studi kasus, simulasi, diskusi, pemecahan masalah, penulisan jurnal), dan sumber mengajar (membaca, tugas rumah, pembicara tamu, teknologi mengajar). ${ }^{12}$ Elemen dasar untuk meningkatkan pembelajaran aktif terdiri dari membuat mahasiswa:

1. Berbicara dan mendengar

Berbicara di dalam kelas merupakan proses pembelajaran aktif yang bertujuan untuk memperjelas apa yang ada dalam pikiran mahasiswa dan juga melatih keterampilan mendengar dan berbicara di depan umum. Dosen memberi kesempatan kepada mahasiswa untuk menyampaikan apa yang mereka pikirkan kepada dosen dan seluruh temannya di kelas tersebut.

Berikut adalah beberapa hal yang bisa digunakan untuk melatih kemampuan berbicara dan mendengarkan:

a. Paraphrasing: meminta mahasiswa untuk menyampaikan kembali apa yang ia tafsirkan dari materi yang ia dengar. Dengan demikian akan melatih keterampilan mendengar aktif.

b. Oral presentation: memberi kesempatan mahasiswa untuk mempresentasikan materi yang telah mereka persiapkan sebelumnya dari materi yang diberikan dosen pada pertemuan sebelumnya. Hal ini bisa melatih keberanian mahasiswa untuk berbicara di depan umum.

c. Amongst student discussion: meminta mahasiswa untuk membaca suatu materi 10-15 menit, kemudian minta salah satu diantara mereka untuk menyampaikan pemahaman mereka terhadap materi tersebut. Lalu minta mahasiswa lain untuk memberikan tanggapan. Dosen bisa memberi pancingan dengan beberapa pertanyaan. Hal ini bisa merangsang proses diskusi dan meningkatkan kemampuan refleksi.

d. Short debate: mahasiswa dibagi menjadi dua kelompok dengan pendapat atau cara pandang yang berbeda terhadap suatu tema. Mereka diminta untuk berdebat, menyampaikan sanggahan terhadap pendapat kelompok lawannya dan mempertahankan pendapat kelompok mereka.

e. Panel: beberapa mahasiswa diminta untuk mempersiapkan presentasi suatu tema dengan sudut pandang yang berbeda dari masing-masing mahasiswa yang bertugas tersebut. Kemudian 
mereka mempresentasikan di depan kelas. Mahasiswa yang bertugas sebagai pendengar diminta untuk bertanya dan memberi tanggapan terhadap materi yang disampaikan oleh temannya tersebut.

2. Membaca atau menulis

Membaca dan menulis dapat mengklarifikasi apa yang dipikirkan oleh mahasiswa dan juga dapat mengembangkan kemampuan menulis mereka. Berikut beberapa cara yang dapat digunakan untuk meningkatkan kemampuan membaca dan menulis:

a. Short reading assignment: menugaskan mahasiswa untuk membaca cepat suatu materi dari buku, jurnal atau satu slide power point dari dosen, kemudian mereka diminta untuk mendiskusikan dengan yang lainnya.

b. Guiding question to the assigned reading: memberikan pertanyaan penuntun kepada mahasiswa saat mereka membaca buku dan meminta mereka untuk menuliskan jawaban mereka.

c. Short writing asignment: minta mahasiswa menuliskan sesuatu di akhir perkuliahan. Perintah menulis bisa berupa pertanyaan isi materi ataupun hal penting yang bisa mereka ambil dari perkuliahan. Kemudian hasil tulisan dikumpulkan kepada dosen untuk mengetahui seberapa banyak pemahaman mahasiswa materi materi yang disampaikan dan juga dapat merangsang mahasiswa untuk belajar aktif.

3. Berpikir dan refleksi

Banyak mahasiswa yang bisa berkonsentrasi ketika mereka mencatat apa yang disampaikan oleh dosen di kelas. Dengan mencatat mereka membangun pemahaman dan pengetahuan mereka terhadap isi perkuliahan. Pertanyaan yang sering muncul adalah bagaimana membuat mahasiswa mengaktifkan pikirannya ketika mereka sibuk membuat catatan? Sehingga beberapa dosen membuat kebijakan untuk meminta mahasiswa fokus pada presentasi tanpa mencatat. Namun demikian banyak mahasiswa yang kesulitan untuk menjadi pendengar pasif tanpa membuat catatan, bahkan beberapa mahasiswa akan mengantuk ketika hanya duduk manis mendengarkan kuliah tanpa mencatat. Oleh karenanya dosen harus bijak menangani hal ini. Bukan dengan melarang mahasiswa mencatat karena khawatir tidak fokus memperhatikan apa yang disampaikan dalam kuliah, tetapi bagaimana memfasilitasi mahasiswa untuk bisa mencari cara bagaimana membuat catatan yang efektif dan bermakna.

Bagaimana membantu mahasiswa untuk membuat catatan yang bermakana? Pertama, jelaskan materi secara bertahap, beri kesempatan mahasiswa untuk berpikir, memahami dan mencatat. Kemudian ijinkan mahasiswa untuk membandingkan catatannya dengan catatan teman mereka dan persilakan mereka untuk menanyakan hal-hal yang masih belum mereka pahami.

4. Bertanya.

Bertanya bisa bermakna pertanyaan dari mahasiswa kepada dosen maupun pertanyaan dari dosen untuk mahasiswa.

Beberapa pendidik dan peneliti menyebutkan bahwa pertanyaan di dalam kelas merupakan aspek yang esensial dalam pembelajaran yang baik. Dalam penelitian Gall (1970) yang disebutkan dalam buku Hativa (2000) disebutkan bahwa pertanyaan yang diberikan dosen di dalam kelas kepada mahasiswanya mempunyai dampak yang besar tehadap prestasi mahasiswa.

Aplikasi teori terhadap pengajaran anatomi di kelas besar

Penulis akan mencoba menerapkan teori diatas untuk pembelajaran anatomi di kelas besar pada mahasiswa paramedis, dimana anatomi merupakan mata kuliah ilmu dasar dengan jadwal tatap muka rutin setiap minggunya. Dengan jumlah pertemuan yang lebih dari satu kali ini maka diharapkan dosen akan lebih mampu menerapkan active learning dan desain 4C/ID.

Untuk pertemuan pertama bisa diberikan overview tentang anatomi, berupa pengantar mengenai definisi, cara belajar, dan istilah-istilah yang sering digunakan dalam anatomi. Mengenai cara belajar disampaikan tentang beberapa pilihan pendekatan dalam pembelajaran anatomi, yaitu pendekatan regional sesuai 
dengan regio tubuh manusia dan pendekatan sistem. Karena pembelajaran yang digunakan dalam kurikulum kedokteran dan kesehatan adalah PBL maka pendekatan sistem inilah yang lebih sesuai. Hal ini sejalan dengan yang disampaikan oleh Kingsbury and Lymn (2008) bahwa dalam PBL menerapkan sistem pembelajaran terintegrasi, yang artinya mengintegrasikan materi dasar dengan kasus klinis, sehingga akan lebih mudah ketika dalam pembelajaran menggunakan pendekatan sistem sesuai dengan kasus klinis yang ada dari masing-masing sistem tubuh. ${ }^{18}$

Setelah overview/pengantar disampaikan, masih dalam pertemuan pertama, dosen membagi mahasiswa ke dalam beberapa kelompok. Sebagai komponen pertama penerapan $4 \mathrm{C} / \mathrm{ID}$ yaitu pemberian tugas, maka masingmasing kelompok diminta untuk mempersiapkan suatu materi yang harus mereka presentasikan pada pertemuan berikutnya. Selain komponen pertama 4C/ID, pada pertemuan pertama ini disampaikan komponen kedua, pemberian informasi penunjang, yaitu penjelasan mengenai istilah-istilah yang sering digunakan dalam anatomi serta buku referensi yang sebaiknya digunakan oleh mahasiswa.

Agar semua mahasiswa fokus pada satu materi inti maka dalam satu pertemuan semua kelompok hanya diberikan satu pokok materi untuk didiskusikan dan dipresentasikan. Mahasiswa mengalami sendiri pencarian sumber informasi dan merangkumnya kemudian mempresentasikannya. Semua ini merupakan bagian dari active learning, yaitu membaca, menulis dan berbicara. Diharapkan dengan active learning ini mahasiswa bisa belajar lebih mendalam terhadap materi tersebut dan akan bertahan lebih lama di dalam memori mereka.

Pada saat mahasiswa mempresentasikan materi mahasiswa lain diminta untuk fokus mendengarkan dan dipersilakan untuk bertanya dan menanggapi apa yang disampaikan oleh presenter. Dosen memberi arahan proses diskusi dan menggaris bawahi hal-hal penting yang perlu diperhatikan oleh mahasiswa, mengoreksi jika ada kesalahan, dan menambahi jika ada materi yang kurang.

Feedback dapat diberikan oleh dosen kepada presenter. Selain itu feedback dapat juga diberikan oleh mahasiswa terhadap rekannya yang presentasi ataupun terhadap jalannya diskusi. Feedback bisa diberikan di akhir presentasi, ditengah-tengah diskusi maupun di akhir diskusi. Sebelum pertemuan ditutup maka mahasiswa diminta menyampaikan kesimpulan dan refleksi mengenai pembelajaran yang mereka terima di sesi tersebut.

\section{KESIMPULAN}

Anatomi merupakan materi dasar dalam pendidikan kesehatan. Pemahaman yang baik mengenai anatomi akan sangat diperlukan untuk lebih memahami pembelajaran kasus-kasus klinis.

Pergeseran kurikulum dalam pendidikan kedokteran maupun kesehatan mengarah pada penerapan kurikulum Problem-based Learning (PBL). Pembelajaran pada kurikulum ini sering terfokus pada kelompok kecil berupa tutorial. Namun demikian perkuliahan dalam kelas besar tidak serta merta hilang, terutama untuk perkuliahan materi dasar seperti anatomi.

Pentingnya materi anatomi untuk dimiliki oleh mahasiswa sebagai bekal untuk menjadi tenaga medis maupun paramedis menjadikan dosen harus berpikir bagaimana agar materi anatomi bisa tersimpan dengan baik dalam memori mahasiswa. Oleh karena itu penulis mencoba bagaimana menerapkan desain instruksional 4C/ID dan prinsip active learning agar bisa memfasilitasi mahasiswa belajar mendalam dan mampu menyimpan memori tentang materi anatomi lebih lama.

\section{DAFTAR PUSTAKA}

1. Drake, Vogl and Mitchell. Gray's Basic Anatomy. 1st ed. Singapura: Elsevier Churcill Livingstone; 2012.

2. Harden and Crosby. AMEE Guide No 20: The good teacher is more than a. Medical Teacher. 2000; 22(4): p. 334-347.

3. Prakosa. Menggagas pembelajaran anatomi pada kurikulum berbasis kompetensi untuk pendidikan kedokteran dasar. Jurnal Anatomi Indonesia. 2006; $1(2)$ : p. 47-52.

4. McKeown et al. The Impact of curricular change on medical student's knowledge of anatomy. Medical Education. 2003; 37: p. 954-961.

5. Ormrod. Psikologi Pendidikan Membantu Siswa Tumbuh dan Berkembang Jilid 2. 6th ed. Jakarta: Erlangga; 2008. 
6. Chilwant. Comparison of two teaching methods, structured interactive lectures. Biomedical Research; 23 (3):. 2012; 23(3): p. 363-366.

7. Cantillon. Teaching Large Groups. In Wood Ca, editor. ABC Learning and Teaching in Medicine. 2 nd ed. Singapore: Blackwell Publishing Ltd; 2010. p. 19. 22.

8. Brown and Manogue. AMEE Medical Education Guide No. 22: Refreshing lecturing: a guide for lecturers. Medical Teacher, Vol. , No. 3,. 2001; 23(3): p. 231-244.

9. Ramsden. Learning to Teach in Higher Education London: Taylor \& Francis e-Library; 2002.

10. Gagne, Briggs and Wager. Principles of Instructional Design. 4th ed. USA: Harcourt Brace Jovanovich ; 1992.

11. Jeffries et al. An Introduction to Medical Teaching New York: Springer Science+Business Media B.V.; 2010.

12. Branch M. Instructional Design: The ADDIE Approach New York: Springer; 2009.
13. van Merriënboer, Clark and de Croock. Blueprints for Complex Learning: The 4C/ID-Model. ETR\&D. 2002; 50(2): p. 39-64.

14. Hativa. Teaching for effective Learning in Higher Education London: Kluwer Academic Publisher; 2000

15. Lowyck, Elen, and Clarebout. Instructional conceptions: Analysis from an Instructional Design Perspektive. International Journal of Educational Research. 2004; 41: p. 429-444.

16. Michaelsen and Sweet M. The essential elements of team based learning. New directions for teaching and learning. 2008; 116: p. 7-27.

17. Harden. A Practical Guide for Medical Teachers Dent , editor. UK: Dundee University; 2001.

18. Kingsbury and Lymn. Problem-based learning and larger student groups: mutually exclusive or compatible concepts - a pilot study. BMC Medical Education. 2008; 8(35): p. 1-10. 